\title{
PENETAPAN WAKAF [ITSBAT WAKAF DI PENGADILAN AGAMA CILEGON

\author{
(Studi Perkara Nomor 281/PDT. P/2011/PA. CLG.)
}

\author{
Zainal Ridho \\ Mahasiswa Program Pascasarjana IAIN Batusangkar \\ Program Studi Hukum Ekonomi Syariah \\ email:rzrronalridho@yahoo.co.id
}

\begin{abstract}
The purpose of this study was to analyze in depth and juridical consideration of the judge in the settlement process petition of Ithbat Waqf in Islamic court of Cilegon case number 281/Pdt.P/2011/ Pa.Clg. Moreover, knowing the validity of nazhir and the position of heir of wakif in case petition of Ithbat Waqf that filed to Religion Court of Cilegon number 281/Pdt.P/2016/PA.Clg. This study was conducted in Islamic Court of Cilegon, using normative or doctrinal research method. Data were collected from the document and copy of the decree of Ithbat Waqf petition number 281/Pdt.P/2016/ PA.Clg. and than re-check with interviewing judges who examine the cases and other participants that related with these case. The conclutions of this study, in general, the legal considerations of the judges are compliance with the provisions of applicable law example absolute authority, incidental power, Law of Waqf, writtten and witness evidence, changes allotment of waqf. But the considerations still incomplete because it doesn't mention clearly the articles that used as the basis for deciding case of Ithbat Waqf, formal and material requirement of evidence, legal standing to litigate in case petition of Ithbat Waqf. Nazhir in this case has legal standing to litigate the petition Ithbat Waqf in Islamic court. And the involvement of the heirs in this case as a witness or as an anticipatory effort at a letter date if there is a dispute over land that has gained egal certainty from Islamic Court.
\end{abstract}

Keyword: Ithbat Waqf, Decree,

\section{PENDAHULUAN}

Keberadaan tanah wakaf sebenarnya telah diakui dalam pasal 49 ayat (3) oleh Undang-undang Nomor 5 tahun 1960 yang menegaskan bahwa perwakafan tanah milik dilindungi dan diatur dengan peraturan pemerintah (Suparman Usman,
1994:132), maka politik hukum agraria nasional juga berlaku terhadap tanah wakaf. Itulah sebabnya semua peraturan perundang-undangan yang mengatur tentang perwakafan tanah menegaskan perlunya pendaftaran tanah wakaf untuk mendapatkan sertifikat wakaf. 
Sebelum Undang-Undang Nomor 5 Tahun 1960 tentang Peraturan Dasar PokokPokok Agraria dan Peraturan Pemerintah Nomor 28 Tahun 1977 tentang Perwakafan Tanah Milik lahir, kebiasaan masyarakat ketika mewakafkan tanah dilakukan secara lisan dari wakif (orang yang mewakafkan) kepada pihak yang dipercaya untuk mengelola tanah wakaf baik oleh berupa perseorangan atau lembaga tertentu.

Pelaksanaan perwakafan tersebut masih sangat sederhana tidak disertai administrasi yang baik, cukup dilakukan ikrar (pernyataan) secara lisan dengan menyerahkan pengurusan dan pemeliharaan tanah wakaf kepada nazhir. Karena tidak tercatat dengan baik maka banyak tanah wakaf tidak mempunyai bukti perwakafan sehingga banyak tanah wakaf yang hilang dan banyak pula yang menjadi sengketa di pengadilan (Imam Suhadi, 2002: 6). Bahkan menurut data yang penulis telusuri hanya 66,25 persen tanah wakaf yang baru memiliki sertifikat dan masih tersisa sejumlah 33,75 persen yang belum bersertifikat. (http://bwi.or.id/index. php/in/publikasi/artikel/1605- mempercepatsertifikasi-tanah-wakaf)

Selanjutnya dalam Peraturan Pemerintah Nomor 28 Tahun 1977 tentang Perwakafan Tanah Milik pada pasal 9 ditegaskan bahwa perwakafan dilakukan secara tertulis, tidak cukup hanya dengan ikrar lisan saja, agar perwakafan tersebut untuk memperoleh bukti otentik, sebagai kelengkapan dokumen pendaftaran obyek wakaf pada Kantor Agraria, maupun sebagai bukti hukum apabila timbul sengketa di kemudian hari tentang obyek yang telah diwakafkan. Karena itu, seseorang yang hendak mewakafkan harus melengkapi dan membawa tanda-tanda bukti kepemilikan dan surat-surat lain yang menjelaskan tidak adanya halangan untuk melakukan pelepasan haknya atas obyek wakaf tersebut. (Taufiq Hamami, 2003, 156, dan Adijani Abilaj, 1997 :34)

Salah satu syarat untuk mendaftarkan sertifikat tanah wakaf adalah dengan Akta Ikrar Wakaf (AIW) atau Akta Pengganti Akta Ikrar Wakaf (APAIW). Dalam kenyataannya banyak tanah wakaf yang tidak memiliki akta tersebut karena wakifnya telah meninggal dunia, dan saat mewakafkan tanah tersebut tidak dilakukan secara tertulis dengan pembuatan akta ikrar wakaf. Padahal upaya memelihara harta benda wakaf dan menjaganya agar tetap ada, tidak rusak, dan tidak hilang, sangat penting sesuai dengan salah satu tujuan umum hukum Islam, yaitu memelihara harta benda wakaf sebagai bagian dari memelihara harta benda (hifzh al-mâl), karena itu benda-benda wakaf yang belum 
ada AIW (akta ikrar wakaf)-nya, dan pewakifnya sudah meninggal kemudian diajukan permohonan itsbat wakaf, atau penetapan wakaf kepada Pengadilan Agama.

Setelah berlakunya Undang-undang Nomor 41 tahun 2004 tentang wakaf, berdasarkan hasil penelusuran dokumen yang peneliti lakukan, Pengadilan Agama Cilegon telah memutus dan menyelesaikan perkara penetapan (itsbat) wakaf, sebanyak 3 perkara yakni tahun 2011, 2013, dan tahun 2014. Salah satu perkara permohonan penetapan (itsbat) wakaf yang telah diputus Pengadilan Agama Cilegon adalah perkara permohonan itsbat wakaf nomor 281/ Pdt. P/2011/PA. Clg.( http:// putusan. mahkamahagung.go.id/pengadilan/PA-cilegon/ direktori/perdata-agama,)

Ada beberapa alasan untuk meneliti lebih jauh perkara Nomor 281/Pdt. P/2011/PA. Clg. yang diputus tahun 2011. Pertama, karena persitiwa wakaf yang akan disahkan terjadi tahun 1941, jauh sebelum ketentuan peraturan tentang perwakafan lahir bahkan sebelum lahrnya Undang-Undang Nomor 5 tahun 1960 tentang Undang-Undang Pokok Agraria. Kedua, kedudukan nazhir yang ditunjuk untuk mengelola tanah wakaf tersebut sudah tidak ada, sedangkan nazhir yang ada sekarang (yang mengajukan perkara ini) adalah Kepala Madrasah Tsanawiyah Pulomerak yang tidak ada hubungan dan penunjukkannya secara langsung dengan nazhir sebelumnya. Ketiga, adanya perubahan peruntukan tanah wakaf yang semula ditujukan untuk makam kemudian beralih status menjadi sarana pendidikan yakni sekolah. Keempat, keterlibatan ahli waris wakif dalam penyelesaian perkara itsbat wakaf ini.

Keluarnya penetapan (itsbat) wakaf di Pengadilan Agama Cilegon bagi peneliti menjadi permasalahan terutama aturan formil tentang kompetensi absolute Pengadilan Agama dalam menangani perkara permohonan (voluntair) itsbat wakaf tersebut. Sebab menurut ketentuan pasal 2 ayat (1) Undang-undang Nomor 14 tahun 1970 sebagaimana telah diubah dengan Undang-Undang Nomor 35 tahun 1999 dan terakhir diubah dengan UndangUndang Nomor 48 tahun 2009 menegaskan tugas dan fungsi kewenangan pengadilan di bidang perdata adalah memeriksa, mengadili dan menyelesaikan perkara yang mengandung sengketa atau yurisdiksi contentiosa yang melibatkan dua pihak baik penggugat dan tergugat dan yurisdiksi contentiosa inilah yang merupakan tugas dan fungsi peradilan yang sebenarnya.

Namun, pengadilan diberikan pengecualian untuk memeriksa dan 
menyelesaikan perkara voluntair terbatas pada hal-hal yang secara tegas ditentukan oleh peraturan perundang-undangan. Dari ketentuan tersebut dapat dipahami bahwa tidak semua perkara dapat diajukan sebagai sebuah perkara permohonan (voluntair). Perkara permohonan dapat diajukan di dan menjadi kewenangan mutlak (absolut) pengadilan sangat terbatas atau sangat eksepsional, yakni dalam hal-hal tertentu atau terhadap masalah yang telah disebut atau ditentukan sendiri oleh peraturan perundangundangan. (M. Yahya Harahap, 2008: 30)

Dalam ketentuan pasal 49 UndangUndang Nomor 7 tahun 1989 sebagaimana telah diubah dengan Undang-Undang Nomor 3 tahun 2006 kemudian terakhir diubah dengan Undang-Undang Nomor 50 tahun 2009 disebutkan bahwa "pengadilan agama bertugas dan berwenang memeriksa, memutus dan menyelesaikan perkara tingkat pertama antara orang-orang yang beragama Islam di bidang : a. perkawinan; b. waris; c. wasiat; d. hibah; e. wakaf; f. zakat; g. infaq; h; shadaqah; dan i. ekonomi syari'ah.(Muhammad Amin Suma,, 2008:503) Ketentuan Pasal 49 tersebut tidak merinci secara jelas jenis perkara voluntair apa saja yang menjadi kewenangan absolute bagi peradilan agama.

Selain itu, dalam ketentuan UndangUndang Nomor 48 Tahun 2009 tentang
Kekuasaan Kehakiman pasal 16 ditegaskan bahwa Pengadilan tidak boleh menolak untuk menerima, memeriksa, mengadili dan memutus suatu perkara yang diajukan dengan dalih bahwa hukum tidak ada atau kurang jelas, melainkan wajib untuk memeriksa dan mengadilinya (Departemen Agama RI, 2004:261).

Dari ketentuan tersebut di atas, dalam perspektif negara hukum bahwa segala sesuatu yang terjadi di masyarakat yang menyangkut persoalan hukum, harus dapat diselesaikan secara hukum pula. Jangan sampai masyarakat menghadapi persoalan hukum kemudian tidak dapat diselesaikan, dengan dalih tidak ada lembaga peradilan yang menanganinya atau tidak ada undang-undang atau hukum yang mengatur tentang persoalan tersebut. Termasuk juga tidak ada alasan bagi hakim untuk tidak memutuskan perkara tersebut, karena hakim tidak tahu dasar pertimbangan putusannya.

Terhadap penetapan perkara permohonan itsbat wakaf ini yang menarik untuk diteliti lebih dalam adalah bagaimana pertimbangan majelis hakim terhadap permasalahan yuridis formal mengenai kompetensi absolute Pengadilan Agama dalam menangani permohonan itsbat wakaf, yang secara enumerative tidak 
disebutkan secara tegas dalam peraturan perundang-undangan yang berlaku.

Selain masalah yuridis formal-nya di atas, hal yang menarik dikaji lebih dalam dari penetapan tersebut adalah pertimbangan majelis hakim dalam menilai bukti-bukti yang diajukan terkait dengan status obyek wakaf guna mengetahui secara benar kedudukan dan seluk-beluk obyek wakaf tersebut dalam memberikan suatu penetapan sesuai dengan peraturan perundang-undangan yang berlaku.

Dalam perkara permohonan itsbat wakaf tersebut juga dimuat adanya peruntukan tanah wakaf yang semula digunakan untuk makam kemudian saat ini di atas tanah wakaf tersebut juga digunakan untuk sekolah. Adanya perubahan peruntukan tersebut, apakah tidak bertetangan dengan peraturan perundang-undangan yang berlaku dan sesuai dengan maksud dan tujuan wakaf semula dari wakif.

Tujuan yang ingin dicapai dalam penelitian ini untuk menganalisis secara mendalam pertimbangan hakim dalam proses penyelesaian permohonan itsbat wakaf di Pengadilan Agama Cilegon perkara nomor 281/Pdt.P/2011/PA. Clg. Kemudian menganalisa secara yuridis pertimbangan hakim dalam penetapan wakaf (itsbat wakaf) di Pengadilan Agama Cilegon perkara nomor 281/Pdt. G/2011/ PA. Clg. Selain itu untuk mengetahui lebih lanjut tentang keabsahan nazhir dalam perkara itsbat wakaf serta kedudukan ahli waris wakif.

\section{METODE PENELITIAN}

Jenis penelitian yang penulis lakukan adalah penelitian hukum normatif atau dikenal juga dengan istilah doctrinal research (Soerjono Soekanto, dan Sri Mamudji, 2009:13-14). Penelitian hukum normatif yang peneliti laksanakan di sini bertujuan untuk menemukan aturan-aturan hukum tentang penyelesaian perkara itsbat wakaf yang berhubungan dengan pertimbangan dan penerapan hukum, sehingga didapat penyelesaian yang pasti terhadap permasalahan tersebut.

Penelitian ini akan dilakukan sejak bulan Mei sampai bulan Agustus 2016, dan tempat penelitiannya di Pengadilan Agama Cilegon, Kotamadya Cilegon, Provinsi Banten. Sumber data yang peneliti gunakan adalah data sekunder, yaitu dokumen berkas perkara dan Salinan Penetapan Pengadilan Agama Cilegon Nomor 281/ Pdt.P/2011/PA.Clg yang putus pada tahun 2011. Selain itu peneliti juga menggunakan data hasil wawancara dengan Hakim Pemeriksa dan para pihak dalam perkara 
yang terkait dengan penelitian ini untuk menguji kebenaran data yang peneliti peroleh.

Agar data-data yang penulis teliti tersebut lebih yakin keasliannya, dalam hal ini penulis menggunakan metode triangulasi (methodological triangulation). (Djamaan Satori dan Aan Komariah, 2011:170-171). Manfaat triangulasi adalah meningkatkan kepercayaan penelitian, menciptakan caracara inovatif dalam rangka memahami fenomena, mengungkap temuan unik, menantang atau mengintegrasikan teori dan memberi pemahaman yang lebih jelas tentang masalah. Dalam hal ini, hasil wawancara dari majelis hakim dalam perkara yang terkait, penulis konfirmasikan ke pihak dalam perkara terkait dengan penelitian ini, kemudian dibandingkan untuk melihat apakah hasil temuan sama.

Selanjutnya data yang penulis peroleh, diolah dengan menggunakan metode deskriptif kualitatif, lalu kemudian penulis hubungkan dengan teori yang berkenaan dengan wakaf, antara lain Undang-Undang Nomor 7 tahun 1989 tentang Peradilan Agama sebagaimana diubah kedua kali dengan Undang-Undang Nomor 48 tahun 2009, Undang-Undang Nomor 41 Tahun 2004 Tentang Wakaf dan Peraturan Pemerintah Nomor 42 Tahun 2006 tentang Peraturan Pelaksanaan Undang-Undang
Nomor 41 Tahun 204 tentang Wakaf, dan teori-teori tentang wakaf menurut para ulama fikih, serta ayat al-Quran maupun Hadits Nabi juga teori-teori Ilmu Hukum yang terkait dengan perkara permohonan (voluntair) dan pembuktian (dalam hal ini terkait dengan saksi istifadhah atau testimonium de auditu).

\section{HASIL PENELITIAN}

\section{Kompetensi Absolut Pengadilan Agama}

Terkait dengan pertimbangan kompetensi absolute tersebut, memang undang-undang tentang peradilan Agama baik Undang-Undang Nomor 7 tahun 1989 maupun perubahannya yakni UndangUndang Nomor 3 tahun 2006 bahkan Undang-Undang Nomor 50 tahun 2009 juga tidak menyebutkan secara tegas kewenangan Pengadilan Agama untuk menangani perkara permohonan itsbat wakaf, yang ada hanya dalam bentuk sengketa.

Meskipun Undang-Undang Peradilan Agama tersebut tidak menyebutkannya namun Pengadilan Agama juga tetap memiliki kewenangan dalam menangani perkara yang diajukan dalam bentuk permohonan seperti itsbat wakaf. Karena kedudukan hakim itu tidak hanya terbatas sebagai corong undang-undang. 
Sudah menjadi kewajiban hakim untuk memeriksa, mengadili dan memutus suatu perkara yang dan tidak ada alasan bagi hakim tidak dapat memutus suatu perkara karena tidak ada aturannya. Di sinilah pentingnya peranan hakim untuk mencari hukumnya dan memutus perkara yang diajukan ke Pengadilan Agama.

Dalam mempertimbangan kompetensi absolut tersebut majelis hakim memuat ketentuan Peraturan Pemerintah Nomor 42 tahun 2006 tentang Peraturan Pelaksanaan Undang-Undang Nomor 41 tahun 2004 tentang wakaf pasal 58. Namun menurut penulis, dari Peraturan Pemerintah Nomor 42 tahun 2006 pasal 58 itu sendiri memunculkan persoalan yang menarik untuk dikaji lebih lanjut yakni ketentuan yang termuat pada ayat 1 huruf $b$ dan $c$.

Menurut peneliti ketentuan Peraturan Pemerintah Nomor 42 tahun 2006 pasal 58 huruf b dan c kedudukannya saling terkait. Pada ketentuan pasal 58 huruf $\mathrm{b}$ dijelaskan tentang harta benda wakaf yang tidak dikuasai secara fisik sebagian atau seluruhnya. Artinya bahwa tanah wakaf yang akan didaftarkan tersebut tidak dikuasai oleh wakif atau nazhir, namun dikuasai oleh pihak ketiga. Karena itu kemudian wakif atau nazhir menyelesaikannya penguasaan fisik tanah wakaf oleh pihak ketiga melalui pengadilan, dan berusaha membuktikan bahwa penguasaan harta benda wakaf oleh pihak ketiga tersebut tersebut tanpa alas hak.

Penguasaan tanah wakaf oleh pihak lain dan harus dibuktikan penguasaan tersebut tanpa alas hak, jelas sekali menunjukkan bahwa persoalan tanah wakaf yang akan didaftarkan namun tanah wakaf tersebut tidak berada dalam penguasaan wakif atau nazhir tetapi dikuasai oleh pihak lain maka berdasarkan ketentuan pasal tersebut upaya hukum untuk menyelesaikan perkaranya adalah dengan mengajukan gugatan bukan dengan permohonan.

Ketentuan pasal 58 huruf c yang menyebutkan bahwa perkara tersebut dikukuhkan dengan penetapan tidak sesuai dengan karakteristik persoalan yang termuat dalam ketentuan pasal 58 huruf $b$ tadi. Seharusnya untuk persoalan yang termuat dalam huruf $b$ dikukuhkan dengan putusan. Sebab pengajuan proses perkara dengan gugatan dan permohonan jelas berbeda. Pengajuan perkara yang mengandung gugatan adalah perkara yang ada sengketa di dalamnya dan melibatkan dua pihak (penggugat melawan tergugat) dan produknya berupa putusan. Sedangkan jika pengajuan perkara dengan permohonan maka yang terlibat hanya satu pihak (dalam hal ini pemohon), tidak 
melibatkan pihak lain (tidak ada pihak lawan) dan tidak mengandung sengketa dan produknya berupa penetapan.

Namun demikian dari pertimbangan tersebut Majelis Hakim sebenarnya tidak hanya mempertimbangkan aspek formilnya saja, di samping itu terdapat alasan hakim Pengadilan Agama Cilegon menerima dan menetapkan permohonan istbat wakaf meskipun undang-undang peradilan agama tidak mengaturnya secara jelas. Pertama, berkaitan dengan asas ius curia novit, yakni hakim dianggap mengetahui hukum (itsbat wakaf) dan asas kebebasan hakim untuk menemukan hukumnya. (rechtsvacum). Kedua, berdasarkan alasan kemashlahatan dan i'tikad baik para pihak. Sebagaimana telah diuraikan di atas bahwa salah satu kepentingan hukum pihak mengajukan istbat wakaf adalah untuk mengurus pendaftaran wakaf.

Dari pertimbangan hakim terhadap penetapan istbat wakaf menurut penulis meskipun Undang-Undang Nomor 7 tahun 1989 tentang Peradilan Agama sebagaimana telah diubah kedua kalinya dengan Undang-Undang Nomor 50 tahun 2009 tidak secara tegas mengatur kompetensi absolut tentang perkara permohonan itsbat wakaf namun dengan mengaitkan pasal 58 huruf c Peraturan Pemerintah Nomor 42 tahun 2006 di atas serta dengan kebebasan yang dimiliki oleh hakim dalam menemukan hukum terhadap suatu perkara, majelis hakim telah mempertimbangkan aspek yuridis dan maslahat dari permohonan itsbat wakaf ini.

Menurut peneliti bahwa aspek maslahat yang dipertimbangkan oleh majelis hakim dalam perkara ini adalah sebagai upaya untuk menjaga harta (hifzul maal) terhadap harta yang sudah diwakafkan berupa makam dan sekolah yang digunakan untuk kepentingan umat. Adanya penetapan dari Pengadilan Agama memberikan kepastian dan jaminan hukum terhadap status wakaf tersebut sehingga akan meminimalisir upaya dari pihak ketiga yang berusaha merebut tanah yang sudah diwakafkan.

Melalui putusan/penetapannya, hakim tidak hanya menerapkan hukum yang ada dalam teks undang-undang (hakim sebagai corong undang-undang) tetapi sesugguhnya hakim juga melakukan pembaharuanpembaharuan hukum ketika dihadapkan pada masalah-masalah yang diajukan kepadanya dan belum diatur dalam undangundang ataupun telah ada aturan tetapi dipandang tidak relevan dengan keadaan dan kondisi yang ada. Inilah fungsi hakim untuk menciptakan hukum baru/jadge made law) untuk menyelesaikan suatu perkara yang diajukan kepadanya (Baqir Manan, 2007:9-13) 


\section{Kuasa Insidentil}

Terkait dengan surat kuasa insidentil dari H. Rafiudin kepada H. Khaeruddin Ghozali, Majelis Hakim tidak mempertimbangkan tentang keabsahan surat kuasa insidentil tersebut, terutama pihak yang dapat memberikan dan menerima kuasa insidentil. Majelis hakim tidak meneliti secara cermat tentang keabsahan kuasa insidentil dalam perkara ini, sebab hubungan antara pemohon (H. Rafiudin) dengan kuasa insidentilnya ( $\mathrm{H}$. Khaerudin Ghozali) hanya sebatas antara Kepala Sekolah dan Guru yang sama-sama bekerja di Madrasah Tsanawiyah Negeri Pulomerak.

Keberadaan kuasa insidentil menurut Surat Edaran Tuada Uldiltun Mahkamah Agung Republik Indonesia Nomor MA/ KUMDIL/8810/1987 dijelaskan bahwa mereka yang mendapat kuasa insidentil yang ditetapkan oleh ketua pengadilan disyaratkan antara pemberi kuasa dan penerima kuasa mempunyai hubungan keluarga dalam batas pengertian isteri atau suami (bukan bekas isteri atau suami), anak-anak yang belum berkeluarga dan orang tua dari suami isteri tersebut.(M. Yahya Harahap,2008:1)

Dari ketentuan tersebut bahwa syarat pertama orang-orang yang mengajukan kuasa insidentil harus mendapat pesetujuan berupa penetapan dari ketua pengadilan dengan melengkapi surat permohonan izin untuk menjadi kuasa insidentil dengan mencantumkan secara jelas kedudukan pihak-pihak berperkara, dalam obyek perkara tertentu dan di Pengadilan tertentu. (Mahkamah Agung RI, 2013:70-71)

Syarat kedua kuasa insidentil yakni adanya hubungan keluarga sampai batas tertentu sehingga hubungan antara pemberi kuasa dan penerima adalah hubungan individual. Agar kuasa insidentil terkontrol maka ketua pengadilan diberi kewenangan pengawasan dengan memberikan syarat bahwa kuasa insidentil hanya bisa beracara jika ada izin ketua pengadilan dan register surat kuasa untuk mengawasi bila ada kuasa insidentil yang beracara berulang-ulang.

Selain sebagai kuasa insidentil sebagaimana tersebut di atas, ternyata H.Khaeruddin Ghozali dalam perkara ini juga berkedudukan sebagai saksi. Padahal H. Rafiudin sebagai pemohon telah memberikan kuasa kepada H. Kherudin Ghozali sebagai kuasa insidentilnya, yang kemudian didaftarkan dalam register pendaftaran surat kuasa khusus Pengadilan Agama Cilegon Nomor : 59/K/2011/ PA.Clg. Dengan demikian seharusnya keterangan H. Khaeruddin Ghozali tidak dapat diterima dalam perkara ini. Alasannya sebab hal tersebut menyalahi 
salah satu asas dalam hukum pembuktian yakni asas nemo in propria causa testis esse debet yang berarti tidak seorang pun boleh menjadi saksi dalam perkaranya sendiri (No one ought to be a witness in his own cause).

(M. Natsir Asnawi,2013:21)

Asas tersebut menegaskan bahwa kedudukan seseorang dalam suatu perkara jika sudah bertindak sebagai pihak, (baik sebagai Penggugat atau Pemohon) tidak dapat bertindak sebagai saksi dalam perkaranya sendiri. Sebab jika pihak yang berperkara juga berkedudukan sebagai saksi dalam perkaranya sendiri maka sangat besar kemungkinan keterangan yang diberikan bersifat subyektif. Karena setiap pihak yanag berperkara pada dasarnya ingin dimenangkan atau dikabulkan perkaranya. Membolehkan pihak untuk menjadi saksi dalam perkaranya sendiri merupakan suatu kekeliruan sebab hampir dapat dipastikan, pihak yang berperkara jika sekaligus menjadi saksi tidak akan memberikan keterangan yang akan merugikan dirinya sendiri. Selain itu juga akan menggangu obyektifitas dari keterangan saksi dalam pembuktian suatu perkara.

\section{Alat Bukti}

Terhadap alat bukti surat berupa surat keterangan Nomor 400/4397/Pmt/2011 yang dikeluarkan oleh Kelurahan Gerem,
Kecamatan Grogol, Kota Cilegon, tanggal 31 Oktober 2011 tersebut, yang diajukan oleh pemohon dalam perkara ini tidak bisa dijadikan sebagai bukti kepemilikan atas tanah wakaf tersebut. Sebab Dalam Undang-Undang Nomor 5 tahun 1960 tentang Peraturan Dasar Pokok-Pokok Agraria atau lebih dikenal dengan UndangUndang Pokok Agraria pada pasal 19 ayat 2 huruf $\mathrm{c}$ yang mengatur tentang pendaftaran tanah diakhiri dengan pemberian surat tanda bukti hak yang berlaku sebagai alat pembuktian yang kuat dan Peraturan Pemerintah Nomor 24 tahun 1997 tentang pendaftaran tanah pasal 4 ayat (1) ditegaskan bahwa untuk memberikan kepastian dan perlindungan hukum kepada pemegang hak atas suatu bidang tanah, satuan rumah susun, dan hak-hak lain yang terdaftar agar dengan mudah dapat membuktikan dirinya sebagai pemegang hak yang bersangkutan, kepada yang bersangkutan diberikan sertifikat hak atas tanah._Oleh karena itu membuktikan suatu bidang tanah tertentu tidak cukup dengan cara menguasainya secara de facto melainkan diperlukan bukti tertentu (de yure) sebagai pendukungnya. (Abdurrahman, 1995:109) Bukti tersebut tidak lain adalah sertifikat hak milik atas tanah sebagai bukti alas hak yang sah dan memiliki kekuatan pembuktian sempurna. 
Selain itu menurut peneliti majelis hakim tidak menilai dan mempertimbangkan tentang syarat formil dan materil alat bukti surat tersebut dalam memutus perkara ini. Seharusnya alat bukti tersebut dipertimbangkan baik syarat formil dan syarat materilnya dalam memutus perkara ini.

Di samping itu setelah penulis teliti ternyata alat bukti surat yang diajukan oleh pemohon tidak dinazegelen (dilakukan pemateraian kemudian). Padahal pemberian bea materai yang diajukan sebagai alat bukti merupakan pajak atas dokumen yang dipakai oleh masyarakat dalam lalu lintas hukum sebagaimana termuat dalam Undang-Undang Nomor 13 tahun 1985 tentang Bea Materai pasal 1 ayat (1) dan menurut Putusan Mahkamah Agung Nomor 589K/Sip/1970, tanggal 13 Maret 1971 yang menegaskan bahwa bukti surat yang tidak diberi meterai tidak merupakan alat bukti yang sah". Akibatnya karena tidak termasuk alat bukti yang sah maka alat bukti tersebut oleh majelis hakim tidak dipertimbangkan ataupun dikesampingkan (Sudikno Merto Kusumo,2006:152-153).

Selain bukti surat, dalam perkara ini, majelis hakim telah mempertimbangkan 4 orang saksi yang diajukan pemohon menyangkut adanya wakaf, walaupun tidak secara langsung menyaksikan sendiri peristiwa pemberian wakaf tersebut, kemudian oleh majelis hakim dikategorikan sebagai syahadah istifadhah (testimonium de auditu).

Peristiwa wakaf yang akan dibuktikan dalam perkara ini terjadi telah lama sekali dan pihak yang terlibat langsung telah meninggal dunia. Secara logika sangat sulit menghadirkan orang-orang yang dapat melihat langsung seluruh rangkaian peristiwa wakaf tersebut, sehingga sangat sulit untuk mendatangkan saksi untuk membuktikannya._Lain halnya dengan peristiwa perdata lainnya yang masih dalam rentang waktu yang baru beberapa tahun terjadi, karena peristiwa yang didalilkan itu adalah peristiwa yang terjadinya dalam satu ruang dan waktu dan telah direncanakan sebelumnya, terlebih lagi misalnya dalam peristiwa jual beli, para pihak yang terlibat di dalamnya pada umumnya sengaja membuat surat/ akta mengenai terjadinya peristiwa jual beli itu, baik itu berupa akta otentik maupun akta bawah tangan, sehingga bila terjadi sengketa, peristiwa tersebut sangat dimungkinkan dibuktikan dengan bukti surat.

Namun meskipun saksi-saksi yang pemohon hadirkan di persidangan hanya sebagai saksi testimonium de auditu tapi 
3 orang saksi tersebut adalah ahli waris wakif yakni masih mempunyai hubungan keluarga dengan wakif, yang mengetahui kebenaran peristiwa wakaf tersebut secara turun temurun. Hal ini sesuai dengan Putusan Mahkamah agung RI Nomor 239 K/Sip/1973 tanggal 25 November 1975 yang menegaskan keterangan saksi pada umumnya adalah menurut pesan namun harus dipertimbangkan dan hampir semua kejadian atau perbuatan hukum yang terjadi pada masa lalu tidak mempunyai surat, tetapi berdasarkan pesan turun temurun. (Muntasir Syukri, 2012:96)

Sementara itu saksi-saksi yang menghadapi perbuatan hukum itu pada masa lalu sudah tidak ada lagi yang hidup sekarang, sehingga dengan demikian pesan turun temurun itulah yang dapat diharapkan sebagai keterangan dan menurut majelis hakim sendiri pesanpesan seperti itu oleh masyarakat tertentu pada umumnya secara adat dianggap berlaku dan benar. Namun demikian yang perlu diperhatikan dari siapa pesan itu diterima berikut orang yang menerima keterangan harus orang yang menerima langsung pesan. Ternyata masalah tersebut sepenuhnya telah terpenuhi di mana orang yang menerangkan pesan di dalam persidangan adalah orang yang langsung menerima pesan.
Kekuatan pembuktian dengan saksi testimonium de auditu tersebut, juga sejalan dengan pendapat ulama syafiyyah dan imam Ahmad dalam kitab figh al Sunnah mengenai bolehnya kesaksian istifadhah dalam persoalan wakaf.(Sayyid Sabiq,1985:427)

\section{Hukum Wakaf}

Majelis hakim hanya mempertimbangkan ketentuan hukum wakaf yang termuat dalam Kompilasi Hukum Islam, dan ketentuan Undang-Undang Nomor 41 tahun 2004 tentang wakaf, tidak menyebutkan secara jelas dan rinci pasal-pasal yang termuat dalam Kompilasi Hukum Islam dan UndangUndang Nomor 41 tahun 2004 tersebut yang dijadikan dasar menentukan terpenuhinya rukun dan syarat wakaf dalam perkara ini.

Seharusnya majelis hakim dalam mempertimbangkan ketentuan hukum wakaf dalam Kompilasi Hukum Islam menyebutkan pasal 215, 217 sampai dengan 219 juga ketentuan yang termuat dalam Undang-Undang Nomor 41 tahun 2004 yakni pasal 6 sampai dengan pasal 10, pasal 15, 17, 18 sampai dengan 20, 22 dan 23.

Sebab menurut ketentuan UndangUndang Nomor 48 tahun 2009 tentang Kekuasaan Kehakiman pasal 50 ayat (1) ditegaskan bahwa Putusan pengadilan selain harus memuat alasan dan dasar 
putusan, juga memuat pasal tertentu dari peraturan perundang-undangan yang bersangkutan atau sumber hukum tidak tertulis yang dijadikan dasar mengadili. Demikian pula yang diatur dalam ketentuan HIR pasal 178 ayat (1) yang mengaskan bahwa hakim memiliki kewajiban untuk melengkapi dasar hukum yang tidak diajukan/disampaikan oleh para pihak.

Bahkan tidak diterapkannya ketentuan hukum tersebut di atas, maka putusan pengadilan dapat dinilai cacat. Namun hal itu bukan dianggap sebagai sebuah cacat serius, masih bisa ditolerir. Sebab kalau cacat yang demikian berakibat membatalkan putusan/ penetapan, tentunya akan merugikan pihak yang berperkara dan mengingkari asas peradilan sederhana, cepat, biaya ringan. (M. Yahya Harahap, 2008:811)

\section{Perubahan Peruntukkan Wakaf}

Terkait dengan perubahan peruntukan wakaf yang semula digunakan untuk makam kemudian untuk madrasah, majelis hakim tidak mencantumkan pasal dari aturan perundang-undangan yang berlaku maupun aturan hukum Islam mengenai bolehnya perubahan peruntukan wakaf yang semula untuk makam kemudian untuk sarana pendidikan yakni sekolah.

Seharusnya dalam pertimbangannya disebutkan pasal-pasal yang terkait perubahan peruntukan wakaf yakni Kompilasi Hukum Islam pasal 225 ayat (1) dan (2) dan Undang-Undang Nomor 41 tahun 2004 tentang wakaf pasal 22.

\section{Amar Penetapan}

Dalam salinan penetapan perkara ini terdapat perbedaan antara amar yang termuat dalam duduk perkara dengan amar yang ada dalam petitum penetapan khususnya tentang peruntukan tanah wakaf untuk madrasah. Seharusnya dalam amar penetapan, majelis hakim secara tegas menyebutkan bahwa tanah wakaf tersebut digunakan untuk Madrasah Tsanawiyah Pulomerak. Sebab penyelesaian pokok perkara tersimpul dalam amar atau diktum penetapan yang merupakan pernyataan yang berkenaan dengan status dan hubungan hukum para pihak dengan objek perkara.(M.Yahya Harahap,2008:811). Dengan kata lain, amar putusan merupakan jawaban atas pokok perkara yang diajukan di persidangan.

Dalam penetapan atau putusan, hakim harus memberikan pertimbangan yang objektif dan rasional mengenai apa saja yang terbukti dan tidak, untuk kemudian merumuskan kesimpulan hukum sebagai dasar landasan penyelesaian perkara yang akan dituangkan di dalam amar atau diktum putusan/penetapan.(M. Yahya Harahap,2008:809) 
Di dalam suatu perkara, kepentingan penggugat/pemohon yang terurai di dalam surat gugatan/permohonannya merupakan titik tolak dari hakim untuk memulai pemeriksaan. Oleh sebab itu yaitu hakim terikat pada gugatan/permohonan yang diajukan oleh penggugat/pemohon untuk kemudian menentukan apakah halhal yang diajukan dan dibuktikan oleh penggugat/pemohon relevan dengan apa yang dituntut.

Produk hukum dalam perkara permohonan itsbat wakaf yang telah diputus oleh majelis hakim Pengadilan Agama Cilegon, pada dasarnya merupakan hukum positif eksepsional dan bersifat solusi. Eksepsional karena pada dasarnya suatu produk peradilan berlaku ke depan, dan tidak surut ke belakang keberlakuan hukumnya (non retroaktif). Dengan itsbat wakaf, suatu produk peradilan berlaku sejak tanggal, bulan dan tahun sebagaimana dibunyikan dalam diktum putusan atau penetapannya, bukan terhitung sejak putusan atau penetapan tersebut berkekuatan hukum tetap (inkracht van gewijsde zaak).

Bersifat solusi karena adakalanya dalam suatu kondisi tertentu, ketika satu dan lain hal, akta ikrar wakaf tidak ada dan juga baik wakif, nazhir serta saksi-saksinya sudah meninggal dunia, maka permohonan itsbat wakaf adalah solusinya. Dalam kasus itsbat wakaf seseorang yang telah mewakafkan tanahnya yang tidak dapat dibuktikan, padahal hendak mengurus pendaftaran tanah wakaf tersebut, dan lembaga yang berkepentingan menetapkan keharusan adanya akta pengganti akta ikrar wakaf, maka akta otentik yang setara untuk mendapatkan akta pengganti ikrar wakaf dapat diperoleh dengan berperkara, mengajukan permohonan itsbat wakaf.

Penetapan Pengadilan Agama tentang itstbat wakaf mencantumkan pernyataan sahnya wakaf yang dilakukan oleh wakif dengan menyebut tanggal, tahun, terjadinya perwakafan. Ini membawa konsekuensi bila penetapan tersebut Berkekuatan Hukum Tetap (BHT) maka status perwakafan tersebut menjadi sah terhitung sejak tanggal perawakafan itu dilaksanakan sebagaimana tercantum dalam amar penetapan. Akibat hukum yang dilahirkan setelah perwakafan itu, yakni untuk madrasah maka sesuai dengan penetapan tersebut adalah sah karena dilahirkan dalam atau sebagai akibat perwakafan yang sah meskipun sejak semula peruntukan untuk tidak diniatkan oleh wakif.

\section{Keabsahan Pemohon Sebagai Nazir}

Terkait dengan keabsahan Pemohon sebagai nazhir, majelis hakim tidak 
mempertimbangkan tentang legal standing pemohon mengajukan perkara itsbat wakaf ini. Padahal pertimbangan legal standing pemohon dalam perkara ini sangat menentukan. Hal ini akan menjelaskan apakah memang pemohon sebagai nazhir dan memiliki hak untuk mengajukan gugatan atau permohonan di depan pengadilan.

Dalam Peraturan Menteri Agama Nomor 1 tahun 1978 bab VIII tentang Tata Cara pendaftaran tanah wakaf yang terjadi sebelum Peraturan Pemerintah Nomor 28 tahun 1977 pada pasal 15 jo Peraturan Pemerintah Nomor 42 tahun 2006 pada pasal 31 dan pasal 35 bahwa pihak yang memiliki kepentingan untuk mengajukan permohonan penetapan itsbat wakaf yaitu wakif dan ahli warisnya, nazhir dan ahli warisnya, saksi dan masyarakat atau yang mengetahui keberadaan tanah wakaf dan kepala desa tempat benda wakaf tersebut berada.

Dalam ketentuan Peraturan Pemerintah Nomor 42 tahun 2006 pasal 4 tersebut nazhir perseorangan yang ditunjuk oleh wakf terdiri paling sedikit 3 (tiga) orang, yang didaftarkan kepada kepada Kementrian Agama dan Badan Wakaf Indonesia melalui Kantor Urusan Agama dimana tanah wakaf tersebut berada. Setelah didaftarkan kemudian Badan Wakaf Indonesia mengeluarkan bukti pendaftaran nazhir. Oleh karena itu menurut peneliti, kedudukan $\mathrm{H}$. Rafiudin yang mengaku sebagai nazhir perseorang tidak terpenuhi dan bertentangan dengan ketentuan Peraturan Pemerintah Nomor 42 tahun 2006 tersebut di atas.

Karena itu kedudukan H. Rafiudin sebagai nazhir terhadap tanah wakaf hanya meliputi tanah Sekolah MtsN Pulomerak saja, sedangkan surat keputusan yang menunjuk H. Rafiudin sebagai nazhir yang mengelola tanah wakaf memang tidak ada. Menurut peneliti berdasarkan ketentuan yang diatur dalam Peraturan Pemerintah Nomor 42 tahun 2006 pasal 4 ayat (2) sebagaimana tersebut di atas harus ada surat keputusan atau bukti pendaftaran yang dikeluarkan oleh Badan Wakaf Indonesia melalui Kantor Urusan Agama setempat. Penunjukan nazhir wakaf tersebut harus berjumlah minimal 3 (tiga) orang.

Karena itu persoalan berikutnya yang harus diselesaikan adalah mendaftarkan nazhir terhadap tanah wakaf tersebut dengan mengurusnya ke Badan Wakaf Indonesia dan Kementerian Agama melalui Kantor Urusan Agama setempat. Hal ini dilakukan guna mendaftarkan nazhir perseorangan yang sah ditunjuk untuk mengelola tanah wakaf tersebut sebanyak 3 (tiga) orang termasuk H. Rafiudin dan juga yang mengelola tanah makam. 


\section{Kedudukan Ahli Waris Wakif}

Terkait keterangan dari 3 orang saksi yang menyatakan bahwa mereka adalah ahli waris dari wakif, dalam pertimbangan perkara ini, yaitu Ismail adalah anak kandung Asnawi, sedangkan Turmuzi bin Hasan adalah cucu dari Kasim, dan Kherudin Ghozali juga cucu dari Hj. Siti masuk dalam kategori ahli waris nasabiyah. yaitu ahli waris yang mempunyai hubungan kewarisan dengan pewaris karena adanya hubungan nasab (darah/keturunan/ kelahiran) Dari hubungan nasab ini, keturunan pewaris wakif berada dalam garis lurus (vertical) ke bawah, seperti anak laki-laki maupun perempuan, cucu dari anak laki-laki maupun perempuan atau disebut furu'ul mayyit.(Mukti Arto, 2009:75-103)

Namun demikian meskipun ketiga saksi tersebut mengaku sebagai ahli waris wakif, seharusnya pengakuan ketiga saksi tersebut bahwa mereka mempunyai hubungan dengan ahli waris dengan wakif juga semestinya dibuktikan. Misalnya dengan surat keterangan ahli waris (penetapan ahli waris) atau ranji tentang ahli waris wakif.

Selain itu majelis hakim tidak menggali lebih lanjut bagaimana bentuk persetujuan atau ketidakkeberatan seluruh ahli waris wakif tentang status tanah wakaf tersebut. Persetujuan secara tertulis dari seluruh ahli waris bisa dibuat dengan akta otentik ataupun akta dibawah tangan.

Sebab menurut pasal 1870 KUH Perdata persetujuan yang dituangkan dalam bukti otententik merupakan bukti yang sempurna tentang apa yang termuat di dalamnya bagi para pihak yang berkepentingan beserta para ahli warisnya ataupun bagi orangorang yang mendapatkan hak dari mereka.

Kedudukan ahli waris wakif yang oleh pemohon dilibatkan secara langsung dengan menjadikannya sebagai saksi dalam perkara permohonan itsbat wakaf, sudah tepat. Hanya saja kedudukan ahli waris wakif semestinya dapat dibuktikan dengan adanya ranji atau surat keterangan yang isinya menjelaskan orang-orang yang berkedudukan sebagai ahli waris dari wakif.

Selain itu, kehadiran ahli waris wakif dalam perkara ini juga sebagai bentuk antisipasi pemohon agar tanah wakaf tersebut kepastian hukum. Sebab dengan melibatkan ahli waris wakif sampai keluarnya penetapan dari Pengadilan Agama, akan mengantisipasi munculnya gugatan sengketa dari ahli waris wakif terhadap tanah tersebut dikemudian hari. 


\section{PENUTUP}

\section{Kesimpulan}

Berdasarkan uraian yang telah dikemukakan di atas, penulis dapat mengambil kesimpulan sebagai berikut:

1. Pertimbangan Hakim dalam proses penyelesaian permohonan itsbat wakaf di Pengadilan Agama Cilegon perkara nomor 281/Pdt.P/2011/PA.Clg, telah memuat pertimbangan tentang kewenangan absolut, Kuasa Insidentil, Hukum wakaf, alat bukti baik tertulis maupun saksi, dan perubahan peruntukan wakaf

2. Meskipun secara umum pertimbangan hukum Majelis Hakim perkara nomor 281/Pdt. P/2011/PA.Clg telah sesuai dengan ketentuan hukum yang berlaku, namun masih kurang lengkap karena tidak mempertimbangkan ketentuan dari pasal-pasal yang dijadikan dasar dalam memutus perkara itsbat wakaf, syarat formil dan materil alat bukti, legal standing pihak yang mengajukan perkara.

3. Kedudukan pemohon sebagai nazhir dalam perkara itsbat wakaf ini secara tidak dapat dibuktikan dengan bukti tertulis dan belum didaftarkan. Namun kedudukan pemohon sebagai pengelola sekolah tetap memiliki hak untuk mengajukan perkara permohonan itsbat wakaf di Pengadilan Agama
Cilegon nomor 281/Pdt. P/2011/ PA. Clg., karena sebenarnya secara de facto pemohonlah yang mengelola dan bertanggung jawab sebagai kepala sekolah MtsN Pulomerak yang berada di tanah wakaf tersebut.

4. Kedudukan ahli waris wakif dengan melibatkannya sebagai saksi dalam perkara permohonan perkara itsbat wakaf ini sudah tepat dan hal itu merupakan upaya antisipatif agar dikemudian hari tidak ada sengketa yang timbul terhadap tanah wakaf yang telah memperoleh kepastian hukum berupa penetapan dari Pengadilan Agama.

\section{Saran}

Berdasarkan beberapa kesimpulan yang dikemukakan di atas, perlu disarankan halhal sebagai berikut:

1. Diharapkan kepada Kepala Sekolah supaya segera mendaftarkan nazhir yang mengelola tanah wakaf tersebut dan mengurus Akta Pengganti Akta Ikrar Wakaf (PPAIW)nya dengan melengkapi dan mengurus administrasi yang terkait dengan pendaftaran tanah wakaf tersebut. Tujuannya agar tanah wakaf tersebut memiliki kepastian hukum dengan adanya sertifikat wakaf.

2. Diharapkan kepada Mahkamah Agung segera mengusulkan aturan tentang 
kompetensi absolut tentang perkara permohonan itsbat wakaf sekaligus pedoman teknisnya sebagai acuan bagi para Hakim di Pengadilan Agama dalam menyelesaikan perkara tersebut.

3. Diharapkan Mahkamah Agung (Pengadilan Agama), Kementerian Agama (Kantor Urusan Agama) dan Menteri Dalam Negeri (Badan Pertanahan Nasional) dapat bekerjasama dalam penyelesaian tanah wakaf yang belum memiliki Akta Ikrar Wakaf ataupun Akta Pengganti Ikrar Wakaf dan sertifikat wakaf melalui sidang Itsbat Wakaf terpadu agar tanah-tanah yang telah diwakafkan memiliki jaminan kepastian hukum.

\section{KEPUSTAKAAN ACUAN}

Abilaj, Adijani. (1997). Perwakafan Tanah di Indonesia Dalam Teori dan Praktek, Jakarta : PT. Rajagrafindo Persada.

Abdurrahman, (1995). Tentang dan Sekitar UUPA, Bandung : Alumni.

Amin Suma, Muhammad. (2008). Himpunan Peraturan Perdata Islam Dan Peraturan Pelaksanaan Lainnya Di Negara Hukum Indonesia, Jakarta : Rajawali Pers.

Arto, Mukti, (1996). Praktek Perkara-Perkara Perdata Pada Pengadilan Agama, Yogyakarta : Pustaka Pelajar.
Asnawi, M. Natsir. (2013). Hukum Pembuktian Perkara Perdata di Indonesia, Kajian Kontekstual Mengenai Sistem Asas, Prinsip Pembeban dan Standar Pembuktian, Yogyakarta : UII Press.

Departemen Agama RI. (2004). Himpunan Peraturan Perundang-Undangan Dalam Lingkungan Peradilan Agama, Jakarta: Direktorat Pembinaan Peradilan Agama,

Hamami , Taufiq. (2003). Perwakafan Tanah Dalam Politik Hukum Agraria Nasional, Jakarta :PT. Tatanusa.

Harahap, M. Yahya. (2008) Hukum Acara Perdata : tentang Gugatan, Persidangan, Penyitaan, Pembuktian dan Putusan Pengadilan, Sinar Grafika, Jakarta.

Manan, Bagir, (2007), Hakim sebagai Pembaharu Hukum, dalam Varia Peradilan Majalah Hukum Tahun Ke XXII No. 254, Jakarta: Ikatan Hakim Indonesia

Mahkamah Agung RI. (2013)Pedoman Pelaksanaan Tugas Dan Administrasi Peradilan Agama, Jakarta: Direktorat Jendral Badan Peradilan Agama.

Mertokusumo, Sudikno. (2006). Hukum Acara Perdata Indonesia, Yogyakarta: Liberty, 
Sabiq, Sayyid. (1985) Fiqh al-Sunnah, Jilid ke-3, Beirut : Dâr al-Kitab al-'Arabiy.

Satori, Djam'an, dan Aan Komariah. (2011). Metodologi Penelitian Kualitatif, Bandung: Alfabeta,

Soekanto, Soerjono dan Sri Mamudji, (2009). Penelitian Hukum Normatif Suatu Tinjauan Singkat, Jakarta : PT Raja Grafindo Persada.

Suhadi, Imam. (2002). Wakaf Untuk Kesejahteraan Umat, Yogyakarta: PT Dana Bhakti Prima Yasa,

Syukri, Muntasyir. (2012) Saksi Di Auditu, dalam Varia Peradilan Majalah Hukum Tahun XXVII No. 319, Jakarta : Ikatan Hakim Indonesia,
Usman, Suparman, Hukum Perwakafan di Indonesia, Serang: Darul Ulum Press, 1994

Undang-Undang Nomor 41 Tahun 2004 tentang Wakaf

Peraturan Pemerintah Nomor 42 Tahun 2006 Tentang Pelaksanaan UndangUndang Nomor 41 tahun 2004 tentang wakaf

http://bwi.or.id/index.php/in/publikasi/ artikel/1605- mempercepat-sertifikasitanah-wakaf

http:// putusan. mahkamahagung.go.id/ pengadilan/PA-cilegon/direktori/ perdata-agama, 